\title{
$\alpha$-lipoic acid can greatly alleviate the toxic effect of AGES on SH-SY5Y cells
}

\author{
GUIFEN NIU $^{1}$, JIANFEI GUO ${ }^{1}$, YAQIANG TIAN ${ }^{2}$, KEXIANG ZHAO $^{3}$, JIAN LI $^{1}$ and QIAN XIAO $^{3}$ \\ ${ }^{1}$ Department of Endocrinology, Liaocheng City People's Hospital, Liaocheng, Shandong 252000; ${ }^{2}$ Department of \\ Endocrinology, Liaocheng Brain Hospital, Liaocheng, Shandong 252000; \\ ${ }^{3}$ Department of the Elderly, Chongqing Medical University, Chongqing 400016, P.R. China
}

Received May 18, 2016; Accepted January 22, 2018

DOI: $10.3892 /$ ijmm.2018.3477

\begin{abstract}
The aim of the study was to explore the influence of $\alpha$-lipoic acid ( $\alpha$-LA) on the cytotoxicity of advanced glycation end-products (AGEs) against SH-SY5Y cells. AGE-bovine serum albumin (BSA) was incubated in vitro using SH-SY5Y cells as a target model, and the control group was set. Cells were exposed to AGE-BSA, and $\alpha$-LA was selectively added to the cells. Cell growth and death was determined by the MTT assay, which measures cellular metabolic rate, lactate dehydrogenase (LDH) leakage rate and cellular axonal length. Immunocytochemistry was employed to detect the expression of $\beta$-amyloid (A $\beta$ ) protein in cells, and mRNA expression of amyloid precursor protein (APP) and the receptor for AGE (RAGE) were assayed by PT-PCR. The metabolism of MTT was clearly increased, the rate of LDH leakage was significantly decreased, and axonal length was significantly increased in cells treated with $\alpha$-LA $(0.1 \mathrm{~g} / \mathrm{l})$ as compared to untreated cells. Furthermore, the expression levels of $A \beta$ protein were also decreased. In addition, $\alpha$-LA $(0.1 \mathrm{~g} / \mathrm{l})$ markedly inhibited the expression of RAGE mRNA, and did not influence APP mRNA expression as compared the control group. $\alpha$-LA $(0.1 \mathrm{~g} / 1)$ was effective at dampening the cytotoxicity of AGE-BSA, a preliminary observation that confirms the ability of $\alpha$-LA to significantly alleviate the cytotoxicity of AGEs against SH-SY5Y cells.
\end{abstract}

\section{Introduction}

It has been reported that diabetes may be an independent risk factor for dementia $(1,2)$. The risks of cognitive impairment and Alzheimer's disease (AD) in type-2 diabetic patients were 1.5- and 1.6-fold of the normal population, respectively (3).

Correspondence to: Dr Qian Xiao, Department of the Elderly, Chongqing Medical University, Chongqing 400016, P.R. China

E-mail: xiaoqianchongqing@126.com

Key words: $\alpha$-lipoic acid, advanced glycation end-products; Alzheimer's disease, $\beta$-amyloid protein, amyloid precursor protein
Furthermore, the degree of brain atrophy seen in AD patients complicated by diabetes was more severe than that seen in AD patients, indicating that diabetes could accelerate the brain aging process of AD patients (4).

Advanced glycation end-products (AGEs) are formed by the irreversible reaction between reducing sugar (glucose) and protein or lipid free radicals (5). The levels of AGEs in diabetes patients were $<5$-fold that seen in non-diabetes individuals, which also plays a very important role in the occurrence and development of chronic diabetes-related complications (6). It was reported that AGEs were present in the senile plaque (SP) and neurofibrillary tangles (NFTS) in the brain of AD patients (7). When AGE accumulation increased, it stimulated glial cells to generate inflammatory factors and increased RAGE expression, making the inflammatory reaction even more severe (8). However, AGEs-RAGE could initiate distinct signaling pathways including p21/Ras, MAP kinase and $\mathrm{NF}-\kappa \mathrm{B}$ in an oxidative stress-dependent manner, and enhance neuronal expression of $\beta$-secretase. This process could further stimulate the generation of some cytokines, growth factors and adhesion molecules, and promote cell proliferation and vascular permeability. In addition, it also caused macrophage migration, stimulated endothelin formation, and promoted the synthesis of proteoglycans and fibers, which thus influenced $\beta$-amyloid (A $\beta$ ) protein secretion (9).

AD was first described by and named after Alzheimer in 1907, which was a primary degenerative disease that occurred in the elderly population. The typical pathologic changes included SP, NFTS, neuronal loss and axonal abnormalities, including astrocyte and microglial cell responses, and vascular amyloid changes. The major component of SP is $\mathrm{A} \beta$, which is derived from the degradation of the amyloid precursor protein (APP) via the A $\beta$ formation pathway. Thus, the influence of APP expression will indirectly regulate formation of $A \beta$ protein.

$A \beta$ is composed of $39-43$ amino acids with a $\beta$-pleated sheet structure. Under normal physiological conditions, $A \beta$ is soluble, its formation, degradation and elimination are in dynamic balance. In the brain of the AD patient, if such balance is destroyed, $A \beta$ will form insoluble precipitation deposits by aggregation and might further lead to SP, which is the initiating factor for the occurrence of AD. Therefore, inhibition of $A \beta$ formation plays a highly significant role in 
AD treatment. Thus, identifying an inhibitory drug therapy will also be very important in the treatment of AD.

$\alpha$-lipoic acid ( $\alpha$-LA) is a natural product that was primarily extracted from pork liver by Reed in 1951. It is an indispensable substance in the tricarboxylic acid cycle and serves as a cofactor for pyruvate dehydrogenase. $\alpha$-LA is metabolized to dihydrolipoic acid in vivo, and exists in the forms of LA and dihydrolipoic acid with synergistic effects that form a universal antioxidant. $\alpha$-LA not only eliminates reactive oxygen and reduce oxidative stress levels, but it also increase GSH concentrations in tissues and prevents sharp decreases in GSH after oxidative damage of tissues (10).

It has been demonstrated that $\alpha$-LA could improve the learning and memory functions in a rat model $(11,12)$, and increased glucose metabolism and insulin sensitivity. Moreover, it could inhibit the developments of diabetic cardiovascular disease, diabetic cataract, diabetic peripheral nerve and autonomic neuropathy. Hager et al (13) attempted to use $\alpha$-LA in the treatment of AD. In that study, 9 patients were orally administrated LA for 1 year, which was the first attempt in the LA-mediated treatment of AD in the clinic. It was found that the cognitive function of the patients was greatly improved by neuropsychological tests (13). However, the mechanism responsible for the ability of LA to protect neurons remains unclear.

In an in vitro study, Zhang et al found that LA could combat the damage that was mediated by the $\mathrm{A} \beta$ peptide and $\mathrm{H}_{2} \mathrm{O}_{2}$ on mouse neurons by activating the PKB/Akt signaling pathway (14). In the latest study, it was also found that $\alpha$-LA inhibited $A \beta$ protein aggregation, reduced $A \beta$ fiber formation and depolymerized the aggregated $\mathrm{A} \beta$ (15). Nevertheless, studies of inhibiting $\mathrm{A} \beta$ formation remain very limited.

In the current study, we employed $\alpha$-LA to treat cells, following which, we observed the protective effect on neurons and explored the possible mechanisms involved in an attempt to provide a theoretical basis for its application in the near future.

\section{Materials and methods}

The source of the cell-line and materials. SH-SY5Y wells were provided by The Institute of Basic Medical Sciences, Chinese Academy of Medical Sciences (Beijing, China). D-glucose 1.1.2 (Amresco, LLC., Solon, OH, USA); MEM culture medium (HyClone, Logan, UT, USA); fetal bovine serum (Zhejiang Tianhang Biotechnology Co., Ltd., Hangzhou, China); $0.1 \%$ pancreatic enzymes, $0.02 \%$ EDTA, BSA and MTT (Beifangtongzheng); lactate dehydrogenase (LDH) test kit (Nanjing Jiancheng Bioengineering Institute, Nanjing, China); RT-PCR reagents (Sangon Biotech Co., Ltd., Shanghai, China); rabbit anti-human A $\beta$ (Wuhan Boster Biological Technology, Ltd., Wuhan, China); SP immumohistochemical staining kit and DAB colour developing reagent kit (ZSGB-BIO, Beijing, China); and $\alpha$-LA (Yabao Pharmaceutical Group Co., Ltd., Beijing, China).

Incubation of SH-SY5Y cells. SH-SY5Y cells were cultured in MEM medium that was supplemented with $10 \% \mathrm{FBS}$, $1 \%$ double-antibody (penicillin and streptomycin) and incubated at $37^{\circ} \mathrm{C}$ and $5 \% \mathrm{CO}_{2}$ in air in a culture flask. The medium was replaced every two days. The cells were digested with $0.1 \%$ pancreatic enzymes (containing $0.02 \%$ EDTA) and seeded at a homogeneous density in a new flask.

Cell counting. The cells were digested as described above, collected and centrifuged at $700 \mathrm{rpm}$ for $5 \mathrm{~min}$. The supernatant was removed, and medium was added. Next, cells were pipetted up and down into a cell suspension. An aliquot of the suspension was taken and mixed with an equal volume of trypan blue. Trace volume of the suspension was dropped on one side of the coverslip in a counting plate, and the suspension did not overflow out of the coverslip. An objective lens $\mathrm{x} 10$ magnification was used to count the cells in the four squares of the counting chamber. If cells were found on the center line, the cell found on the left and top left was counted. The cell density was calculated as follows: Cell number $/ \mathrm{ml}$ original medium $=($ sum of cell number in 4 squares $/ 4) \times 10^{4} \times 2$.

Preparation for AGE-BSA. FBS $5 \mathrm{~g} / 1$, D-glucose $0.5 \mathrm{M}$, penicillin $100 \mu / 1$, streptomycin $100 \mu / \mathrm{l}$ and EDTA $1 \mathrm{mmol} / \mathrm{l}$ were dissolved in PBS ( $\mathrm{pH} 7.4$ ), then filtered by $0.22 \mu \mathrm{m}$ microfiltration membrane and incubated at $37^{\circ} \mathrm{C}$ avoiding light for three months. The systems with the same FBS but under conditions of different glucose concentrations were used as control. PBS ( $\mathrm{pH}$ 7.4) was used to dialyze the unbound glucose before use. The solution was stored at $-20^{\circ} \mathrm{C}$. AGEs was detected by a fluorospectrophotometer (4).

Grouping. First, the cells were divided into three groups randomly. Group 1 was the control group without any processing; group 2 was treated by different BSA concentrations (terminal concentrations of $0,20,40,80,160$ and $320 \mu \mathrm{g} / \mathrm{ml}$ ) for $48 \mathrm{~h}$; and group 3 was treated by different AGE-BSA concentrations (terminal concentrations of $0,20,40,80,160$ and $320 \mu \mathrm{g} / \mathrm{ml}$ ) for $48 \mathrm{~h}$. According to the results of the above experiment, group 4 was added, which represented cells treated by different $\alpha$-LA concentrations (terminal concentrations of $0.01,0.1$ and $1 \mathrm{~g} / \mathrm{l}$ ) to intervene in cells $30 \mathrm{~min}$ prior to AGE-BSA $(160 \mu \mathrm{g} / \mathrm{ml})$ treatment, which was then added to treat the cells for $48 \mathrm{~h}$. According to the result of group 4, group 5 was added, which included treatment by $\alpha$-LA $(0.1 \mathrm{~g} / \mathrm{l})$ to intervene cells $30 \mathrm{~min}$ prior to AGE-BSA $(80 \mu \mathrm{g} / \mathrm{ml})$ treatment for $48 \mathrm{~h}$. The cell growth state were assayed by MTT metabolic rate, LDH leakage rate and cell axonal length. Immunocytochemistry was used to detect $A \beta$ protein expression. Further, mRNA expression of APP and RAGE were tested by RT-PCR wherein the AGE-BSA concentration was chosen that slightly influenced cell growth. The concentration in each control group was found to be consistent with group 3 .

MTT assay. SH-SY5Y cells were seeded at a density of $5 \times 10^{4} / \mathrm{ml}$ in 96 well-plates and incubated in $200 \mu \mathrm{l}$ medium. Serum-free medium was added to replace the original medium after $24 \mathrm{~h}$ of culture. The cells were randomly divided into five groups. Group 1 was added with different BSA concentrations $(0,20,40,80,160$ and $320 \mu \mathrm{g} / \mathrm{ml})$ for $48 \mathrm{~h}$; group 2 was treated by different AGE-BSA concentrations $(0,20,40,80,160$ and $320 \mu \mathrm{g} / \mathrm{ml})$ for $48 \mathrm{~h}$. Group 3 was treated by different $\alpha$-LA concentrations $(0.01,0.1$ and $1 \mathrm{~g} / \mathrm{l})$ to intervene in cells $30 \mathrm{~min}$ earlier and then AGE-BSA 


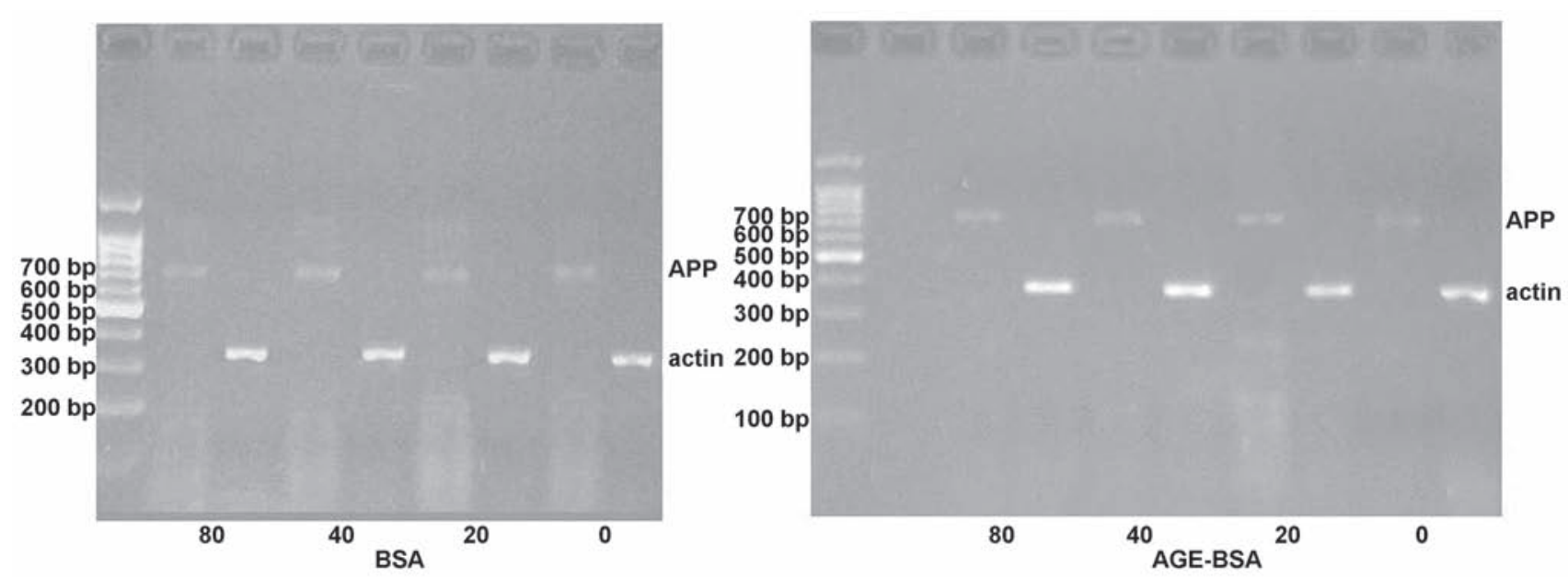

Figure 1. Expression of APP mRNA in SH-SY5Y cells dose-dependently treated by BSA and AGE-BSA. BSA, bovine serum albumin; AGE, advanced glycation end-product; APP, amyloid precursor protein.

$(160 \mu \mathrm{g} / \mathrm{ml})$ was added to treat cells for $48 \mathrm{~h}$. Group 4 was added to introduce treatment of cells with $\alpha$-LA $(0.1 \mathrm{~g} / \mathrm{l})$ for 30 mins followed by treatment by AGE-BSA $(80 \mu \mathrm{g} / \mathrm{ml})$ for $48 \mathrm{~h}$. Group 5 was a control treatment in the absence of any treatment. After $48 \mathrm{~h}$ of treatment, $5 \mathrm{mg} / \mathrm{ml}$ of MTT reagent (20 $\mu \mathrm{l}$ ) was added to each well. The cells were further incubated for $4 \mathrm{~h}$ at $37^{\circ} \mathrm{C}$, which were then collected, centrifuged and washed once in culture medium without serum. DMSO (150 $\mu \mathrm{l})$ was added to each well and shaken for $10 \mathrm{~min}$ to completely dissolve the formazan crystals. The optical density (OD) at a test wavelength of $570 \mathrm{~nm}$ was read by an automatic microplate reader. The cell viability in the control group was set as $100 \%$, and the MTT metabolic rate was calculated by the ratio of $\mathrm{OD}$ to the control.

LDH release assay. SH-SY5Y cells were seeded at $5 \times 10^{4} / \mathrm{ml}$ in 24 well-plates and incubated in $1 \mathrm{ml}$ medium. Medium without serum was added to replace the original after $24 \mathrm{~h}$. The groups were the same as described for the MTT assay. Culture medium in each group was taken after $48 \mathrm{~h}$, and OD values of the medium were measured by ultraviolet spectrophotometry at $440 \mathrm{~nm}$ according to the manufacturer's instruction. Furthermore, the best sample volume was obtained from the standard curve.

Detection for cell axon length. SH-SY5Y cells were seeded at a density of $5 \times 10^{4} / \mathrm{ml}$ in $35 \mathrm{~mm}$ culture flasks. Serum-free medium was added to replace the original after $24 \mathrm{~h}$. The groups were the same as that described for the MTT assay. Photographic images of cells (random sampling of 30 cells) were taken $48 \mathrm{~h}$ after treatment by inverted phase contrast microscopy and the cell axon length was analyzed by pathologic image analysis.

Detection of APP mRNA and AGER mRNA by RT-PCR. The $\beta$-actin amplified fragment was $318 \mathrm{bp}$. Forward primer: 5'-ATCATGTTTGAGACCTTCAACA-3'. Reverse primer: 5'-CATCTCTTGATCGAAGTCCA-3'. The APP amplified fragment was 704 bp. Forward primer: 5'-CACATCCCTGGG CTTACGGT-3'. Reverse primer: 5'-TCAAGTTGGAGGCGG
AGTTGC-3'. The RAGE: amplified fragment was $376 \mathrm{bp}$. Forward primer: 5'-GGCTGGTGTTCCCAATAAGG-3'. Reverse primer: 5'-ACAGGTCAGGGTTACGGTTC-3'. Detection of SH-SY5Y intracellular A $\beta$ levels by immunocytochemistry. Wells with SH-SY5Y cells were seeded at a density of $5 \times 10^{4} / \mathrm{ml}$ in 6 -well plates. A small slide was placed in the plate before seeding. The assigned groups were as described for the MTT assay.

Statistical analysis. All data were analyzed by SPSS v.13.0 (SPSS, Inc. Chicago, IL, USA), and Microsoft Excel. The data are represented as mean $\pm \mathrm{SD}$. The comparisons of measured data among multiple groups were analyzed by one-way analysis of variance to determine the homogeneity test of variance. An $\alpha$ value of $\mathrm{P}<0.05$ was considered to indicate a statistically significant difference.

\section{Results}

Fluorescence identification for AGEs-BSA. After 90 days of incubation of cells with BSA and D-glucose, the fluorescence spectrum of AGEs-BSA showed that the excitation spectrum peak and emission spectrum peak were at 360 and $446 \mathrm{~nm}$, respectively, in accordance with the characteristics of AGEs. However, that of the control BSA group had no such feature (Fig. 1).

The influence of BSA/AGE-BSA concentration on growth of $S H-S Y 5 Y$. When the concentration of AGE-BSA exceeded $40 \mu \mathrm{g} / \mathrm{ml}$, the growth of SH-SY5Y cells was influenced in a concentration-dependence manner, which led to decreased MTT metabolic rate, increased LDH release and a shortening in the axon length. It was suggested that AGE-BSA had evidently damaged neurons, which was in line with the studies of Wolter et al (16) and Takeuchi et al (17).

Compared with the control group, there was no significant difference in MMT metabolic rate in the BSA treated groups. AGE-BSA at $40 \mu \mathrm{g} / \mathrm{ml}$ reduced the MMT metabolic rate significantly $(\mathrm{P}<0.05)$ and further decreased in an increasing concentration-dependent manner until reaching the lowest 
Table I. Concentration-dependent effect of BSA/AGE-BSA at $48 \mathrm{~h}$ on the MTT metabolic rate of SH-SY5Y cells.

\begin{tabular}{lcc}
\hline & \multicolumn{2}{c}{ MTT metabolic rate } \\
\cline { 2 - 3 } Groups $(\mu \mathrm{g} / \mathrm{ml})$ & BSA group & AGE-BSA group \\
\hline Control & $1 \pm 0$ & $1 \pm 0$ \\
20 & $1.0019 \pm 0.0213$ & $0.9902 \pm 0.0143$ \\
40 & $1.0001 \pm 0.0222$ & $0.9346 \pm 0.0209^{\mathrm{a}, \mathrm{b}}$ \\
80 & $0.9952 \pm 0.0222$ & $0.8783 \pm 0.0188^{\mathrm{a}, \mathrm{b}}$ \\
160 & $0.9922 \pm 0.0213$ & $0.6434 \pm 0.0178^{\mathrm{c}, \mathrm{d}}$ \\
320 & $0.9928 \pm 0.0256$ & $0.3406 \pm 0.0124^{\mathrm{c}, \mathrm{d}}$ \\
\hline
\end{tabular}

Data are presented as the means $\pm \mathrm{SD}$. vs. Control, ${ }^{\mathrm{a}} \mathrm{P}<0.05$; vs BSA, ${ }^{\mathrm{b}} \mathrm{P}<0.05$, vs. control, ${ }^{\mathrm{c}} \mathrm{P}<0.01$, vs. $\mathrm{BSA},{ }^{\mathrm{d}} \mathrm{P}<0.01$. BSA, bovine serum albumin; AGE, advanced glycation end-product.

Table II. Concentration-dependent effect of BSA/AGE-BSA on LDH release by SH-SY5Y cells.

\begin{tabular}{lcc}
\hline \multirow{2}{*}{ Groups } & \multicolumn{2}{c}{ LDH leakage rate $(\mu / \mathrm{l})$} \\
\cline { 2 - 3 } & \multicolumn{1}{c}{ BSA } & AGE-BSA \\
\hline Control & $431.15 \pm 65.19$ & $431.15 \pm 65.19$ \\
20 & $438.21 \pm 13.06$ & $483.53 \pm 15.02$ \\
40 & $451.83 \pm 10.26$ & $739.57 \pm 67.02^{\mathrm{a}, \mathrm{b}}$ \\
80 & $453.90 \pm 17.85$ & $1066.35 \pm 300.96^{\mathrm{a}, \mathrm{b}}$ \\
160 & $447.80 \pm 24.61$ & $1608.22 \pm 141.3^{\mathrm{c}, \mathrm{d}}$ \\
320 & $441.21 \pm 19.32$ & $2500.45 \pm 146.48^{\mathrm{c}, \mathrm{d}}$
\end{tabular}

Data are presented as the means \pm SD. vs. Control, ${ }^{\mathrm{a}} \mathrm{P}<0.05$; vs. BSA group, ${ }^{\mathrm{b}} \mathrm{P}<0.05$; vs. control, ${ }^{\mathrm{c}} \mathrm{P}<0.01$, vs. $\mathrm{BSA},{ }^{\mathrm{d}} \mathrm{P}<0.01$. BSA, bovine serum albumin; $\mathrm{LDH}$, lactate dehydrogenase; AGE, advanced glycation end-product; SD, standard deviation.

level at $320 \mu \mathrm{g} / \mathrm{ml}(\mathrm{P}<0.01)$. A comparison of the AGE-BSA concentration group and the BSA alone group at the same concentration, demonstrated that the rate was significantly reduced at $40,80,160,320 \mu \mathrm{g} / \mathrm{ml}(\mathrm{P}<0.05)$. Although the group treated by $20 \mu \mathrm{g} / \mathrm{ml}$ was lower than the control group, it was not statistically significant (Table I).

Compared with the control group, there was no significant difference on LDH release in the BSA treated groups. AGE-BSA at a concentration of $40 \mu \mathrm{g} / \mathrm{ml}$ increased the release of LDH significantly $(\mathrm{P}<0.05)$ and reached the highest level at $320 \mu \mathrm{g} / \mathrm{ml}(\mathrm{P}<0.01)$. The comparison of the AGE-BSA concentration group and the BSA alone group at the same concentrations demonstrated that the rate was significantly reduced at 40, 80, 160 and $320 \mu \mathrm{g} / \mathrm{ml}(\mathrm{P}<0.05)$. Although the group treated with $20 \mu \mathrm{g} / \mathrm{ml}$ was lower than the control group, it was not statistically significant (Table II).

Compared with the control group, there was no significant difference in cell axon length in the BSA treated groups. In addition, $40 \mu \mathrm{g} / \mathrm{ml}$ AGE-BSA shortened the length significantly $(\mathrm{P}<0.05)$ and shortened gradually as concentration increased
Table III. Effect of different concentrations of BSA/AGE-BSA on axonal length of SH-SY5Y cells.

Axonal length (Pixel total points)

\begin{tabular}{llc}
\cline { 2 - 3 } Groups $(\mu \mathrm{g} / \mathrm{ml})$ & BSA $(\mu \mathrm{g} / \mathrm{ml})$ & AGE-BSA $(\mu \mathrm{g} / \mathrm{ml})$ \\
\hline Control & $42.00 \pm 12.78$ & $42.15 \pm 10.00$ \\
20 & $40.45 \pm 11.48$ & $41.52 \pm 11.40$ \\
40 & $41.94 \pm 10.88$ & $35.44 \pm 9.19^{\mathrm{a}, \mathrm{b}}$ \\
80 & $40.23 \pm 11.34$ & $28.69 \pm 6.88^{\mathrm{a}, \mathrm{b}}$ \\
160 & $40.82 \pm 11.45$ & $21.13 \pm 5.61^{\mathrm{c}, \mathrm{d}}$ \\
320 & $41.91 \pm 9.01$ & $12.47 \pm 5.56^{\mathrm{c}, \mathrm{d}}$
\end{tabular}

Data are presented as the means $\pm \mathrm{SD}$. vs. Control, ${ }^{\mathrm{a}} \mathrm{P}<0.05$; vs. BSA, ${ }^{\mathrm{b}} \mathrm{P}<0.05$; vs. control, ${ }^{\mathrm{C}} \mathrm{P}<0.01$, vs. BSA, ${ }^{\mathrm{d}} \mathrm{P}<0.01$. BSA, bovine serum albumin; AGE, advanced glycation end-product; SD, standard deviation.

until reaching a peak at $320 \mu \mathrm{g} / \mathrm{ml}(\mathrm{P}<0.01)$. The comparison of the AGE-BSA concentration group and the BSA alone group at the same concentrations demonstrated that the length was significantly short at 40, 80, 160 and $320 \mu \mathrm{g} / \mathrm{ml}(\mathrm{P}<0.05)$. Although the group treated with $20 \mu \mathrm{g} / \mathrm{ml}$ was shorter than that of the control group, the observation was not significantly different (Table III).

Influence of BSA/AGE-BSA concentration on $A \beta$ protein expression in $S H-S Y 5 Y$ cells. The color of positive $A \beta$ protein expression was brownish red. In the control group, $A \beta$ protein expression was decreased in the cytoplasm. As compared with control group, there was no significant change in terms of $A \beta$ protein expression in the cytoplasm of cells that were dose-dependently treated by BSA. However, those treated by different AGE-BSA concentrations showed a significant difference $(\mathrm{P}<0.05)$. Compared with the corresponding BSA concentration group, $A \beta$ protein expression in the cytoplasm was significantly increased following treatment with AGE-BSA (P<0.05; Table IV).

Influence of AGE-BSA concentrations on APP $m R N A$ expression in SH-SY5Y cells. The group with the least influence on the state of cell growth was chosen. Compared with the control group, there was no significant difference on APP mRNA expression following treatment with AGE-BSA, or the BSA groups (Table V).

Influence of BSA/AGE-BSA concentration on RAGE $m R N A$ expression in $S H-S Y 5 Y$ cells. Compared with control group, there was no significant difference on RAGE mRNA expression following treatment with BSA alone. In the AGE-BSA group, the RAGE mRNA expression was significantly increased at $20 \mu \mathrm{g} / \mathrm{ml}(\mathrm{P}<0.05)$. Moreover, at $40 \mu \mathrm{g} / \mathrm{ml}$ and $80 \mu \mathrm{g} / \mathrm{ml}$, RAGE mRNA expression showed a significant difference as compared with the control group (RAGE mRNA). As compared with the corresponding BSA concentration group, RAGE mRNA expression was significantly increased following treatment with AGE-BSA $(\mathrm{P}<0.05$; Table VI and Fig. 2). 
Table IV. Dose-dependent effect of different concentrations of BSA/AGE-BSA on expression of A $\beta$ protein in $\mathrm{SH}-\mathrm{SY} 5 \mathrm{Y}$ cells.

\begin{tabular}{lll}
\hline \multirow{2}{*}{ Groups $(\mu \mathrm{g} / \mathrm{ml})$} & \multicolumn{2}{c}{$\mathrm{A} \beta$ protein $(\mathrm{OD}$ value $)$} \\
\cline { 2 - 3 } Control & BSA group & AGE-BSA group \\
20 & $0.129 \pm 0.025$ & $0.129 \pm 0.025$ \\
40 & $0.126 \pm 0.017$ & $0.167 \pm 0.029^{\mathrm{a}, \mathrm{b}}$ \\
80 & $0.125 \pm 0.022$ & $0.226 \pm 0.076^{\mathrm{a}, \mathrm{b}}$ \\
& $0.128 \pm 0.018$ & $0.309 \pm 0.073^{\mathrm{c}, \mathrm{d}}$
\end{tabular}

vs. control, ${ }^{\mathrm{a}} \mathrm{P}<0.05$; vs. group $\mathrm{BSA},{ }^{\mathrm{b}} \mathrm{P}<0.05$; vs. control, ${ }^{\mathrm{c}} \mathrm{P}<0.01$, vs. BSA, ${ }^{\mathrm{d} P}<0.01$. BSA, bovine serum albumin; AGE, advanced glycation end-product; SD, standard deviation; OD, optical density; $\mathrm{A} \beta, \beta$-amyloid.

Table V. Dose-dependent effect of BSA/AGE-BSA on the expression of APP mRNA in SH-SY5Y cells.

\begin{tabular}{lcc}
\hline \multirow{2}{*}{ Groups $(\mu \mathrm{g} / \mathrm{ml})$} & \multicolumn{2}{c}{ APP mRNA/actin mRNA } \\
\cline { 2 - 3 } 0 & BSA group & AGE-BSA group \\
\hline 20 & $0.284 \pm 0.033$ & $0.284 \pm 0.033$ \\
40 & $0.290 \pm 0.032$ & $0.283 \pm 0.025$ \\
80 & $0.289 \pm 0.027$ & $0.281 \pm 0.026$ \\
& $0.288 \pm 0.019$ & $0.286 \pm 0.020$ \\
\hline
\end{tabular}

Data are presented as the means $\pm \mathrm{SD}$. BSA, bovine serum albumin; AGE, advanced glycation end-product; SD, standard deviation; APP, amyloid precursor protein.

Table VI. Dose-dependent effect of BSA/AGE-BSA on mRNA expression of RAGE in SH-SY5Y cells.

\begin{tabular}{lcc}
\hline & \multicolumn{2}{c}{ RAGE mRNA/actin mRNA } \\
\cline { 2 - 3 } Groups $(\mu \mathrm{g} / \mathrm{ml})$ & BSA group & AGE-BSA group \\
\hline 0 & $0.491 \pm 0.017$ & $0.491 \pm 0.017$ \\
20 & $0.494 \pm 0.027$ & $0.522 \pm 0.031^{\mathrm{a}, \mathrm{b}}$ \\
40 & $0.507 \pm 0.013$ & $0.542 \pm 0.026^{\mathrm{a}, \mathrm{b}}$ \\
80 & $0.486 \pm 0.010$ & $0.591 \pm 0.040^{\mathrm{a}, \mathrm{b}}$ \\
\hline
\end{tabular}

Data are presented as the means $\pm \mathrm{SD}$. vs. Control, ${ }^{\mathrm{P}}<0.05$; vs. BSA group, ${ }^{b} \mathrm{P}<0.05$. BSA, bovine serum albumin; AGE, advanced glycation end-product; RAGE, receptor for AGE; SD, standard deviation.

Observation of cell growth state following dose-dependent intervention with $\alpha-L A$. According to the above results, the cells in the AGE-BSA $160 \mu \mathrm{g} / \mathrm{ml}$ ) group were chosen. In the $\alpha$-LA $(0.1 \mathrm{~g} / \mathrm{l})$ intervention group, the MMT metabolic rate significantly increased, LDH release significantly decreased, and axonal length significantly increased as compared
Table VII. Levels of MTT metabolic rate, LDH release rate and axonal length in SH-SY5Y cells following intervention by LA before treatment with $160 \mu \mathrm{g} / \mathrm{ml}$ AGE-BSA.

\begin{tabular}{lccc}
\hline $\begin{array}{l}\text { Groups } \\
(\mathrm{g} / \mathrm{l})\end{array}$ & $\begin{array}{c}\text { MTT } \\
\text { metabolic rate }\end{array}$ & $\begin{array}{c}\text { LDH leakage } \\
\text { rate }(\mu / \mathrm{l})\end{array}$ & $\begin{array}{c}\text { Axon length } \\
\text { (Pixel total points) }\end{array}$ \\
\hline Control & $0.643 \pm 0.018$ & $1608.22 \pm 141.37$ & $21.13 \pm 5.61$ \\
0.01 & $0.684 \pm 0.022$ & $1538.40 \pm 102.07$ & $22.33 \pm 4.81$ \\
0.1 & $0.840 \pm 0.068^{\mathrm{a}}$ & $1151.70 \pm 146.47^{\mathrm{a}}$ & $29.11 \pm 7.56^{\mathrm{a}}$ \\
1 & $0.630 \pm 0.029$ & $1662.52 \pm 110.82$ & $20.89 \pm 3.68$ \\
\hline
\end{tabular}

Data are presented as the means \pm SD. vs control, ${ }^{\mathrm{a}} \mathrm{P}<0.05$. BSA, bovine serum albumin; LDH, lactate dehydrogenase; AGE, advanced glycation end-product; SD, standard deviation; LA, lipoic acid.

Table VIII. Levels of A $\beta$ protein expression in SH-SY5Y cells that were intervened by LA before being treated with $80 \mu \mathrm{g} / \mathrm{ml}$ AGE-BSA.

\begin{tabular}{lc}
\hline Groups & $\mathrm{A} \beta$ protein (OD value) \\
\hline $80 \mu \mathrm{g} / \mathrm{ml}$ AGE-BSA & $0.309 \pm 0.073$ \\
$0.1 \mathrm{~g} / \mathrm{l} \mathrm{LA}$ & $0.213 \pm 0.046^{\mathrm{a}}$ \\
Control & $0.129 \pm 0.025$ \\
\hline
\end{tabular}

Data are presented as the means \pm SD. vs. $80 \mu \mathrm{g} / \mathrm{ml}$ AGE-BSA group, ${ }^{a} \mathrm{P}<0.01$. BSA, bovine serum albumin; AGE, advanced glycation end-product; SD, standard deviation; LA, lipoic acid; $A \beta, \beta$-amyloid; OD, optical density.

with that of the control group $(\mathrm{P}<0.05)$. Compared with the AGE-BSA $(160 \mu \mathrm{g} / \mathrm{ml})$ group, it was noted that the $\alpha$-LA $(0.01 \mathrm{~g} / 1)$ intervention group showed an increased MMT metabolic rate, a decreased LDH release rate and increased axonal length as compared that of the control group - although this was not significantly different. It is interesting to note that the protective effect in the $\alpha$-LA ( $1 \mathrm{~g} / \mathrm{l})$ intervention group disappeared. Compared with the control group, there was no evident changes in MTT metabolic rate or axonal length, and yet $\mathrm{LDH}$ release slightly increased $(\mathrm{P}>0.05$; Table VII).

According to the above described results, it was found that $\alpha$-LA $(0.1 \mathrm{~g} / \mathrm{l})$ was protective for SH-SY5Y cells under treatment by $160 \mu \mathrm{g} / \mathrm{ml} \mathrm{AGE-BSA}$. Thus, we selected the cells in the AGE-BSA $(80 \mu \mathrm{g} / \mathrm{ml})$ group, and used $\alpha$-LA at $0.1 \mathrm{~g} / 1$ to intervene in the cells. Compared with the AGE-BSA $(80 \mu \mathrm{g} / \mathrm{ml})$ group, the $\mathrm{A} \beta$ expression significantly decreased in the intervention group $(\mathrm{P}<0.01$; Table VIII).

The cells in the AGE-BSA $(80 \mu \mathrm{g} / \mathrm{ml})$ group were chosen. In the $\alpha$-LA $(0.1 \mathrm{~g} / \mathrm{l})$ intervention group, there were no evident changes in APP mRNA as compared with the control group (Table IX and Fig. 3).

Changes in RAGE mRNA expression in cells intervened by $\alpha$-LA $(0.1 \mathrm{~g} / \mathrm{l})$. The cells in the AGE-BSA $(8 \mu \mathrm{g} / \mathrm{ml})$ group were chosen. In the $\alpha$-LA $(0.1 \mathrm{~g} / \mathrm{l})$ intervention group, there 


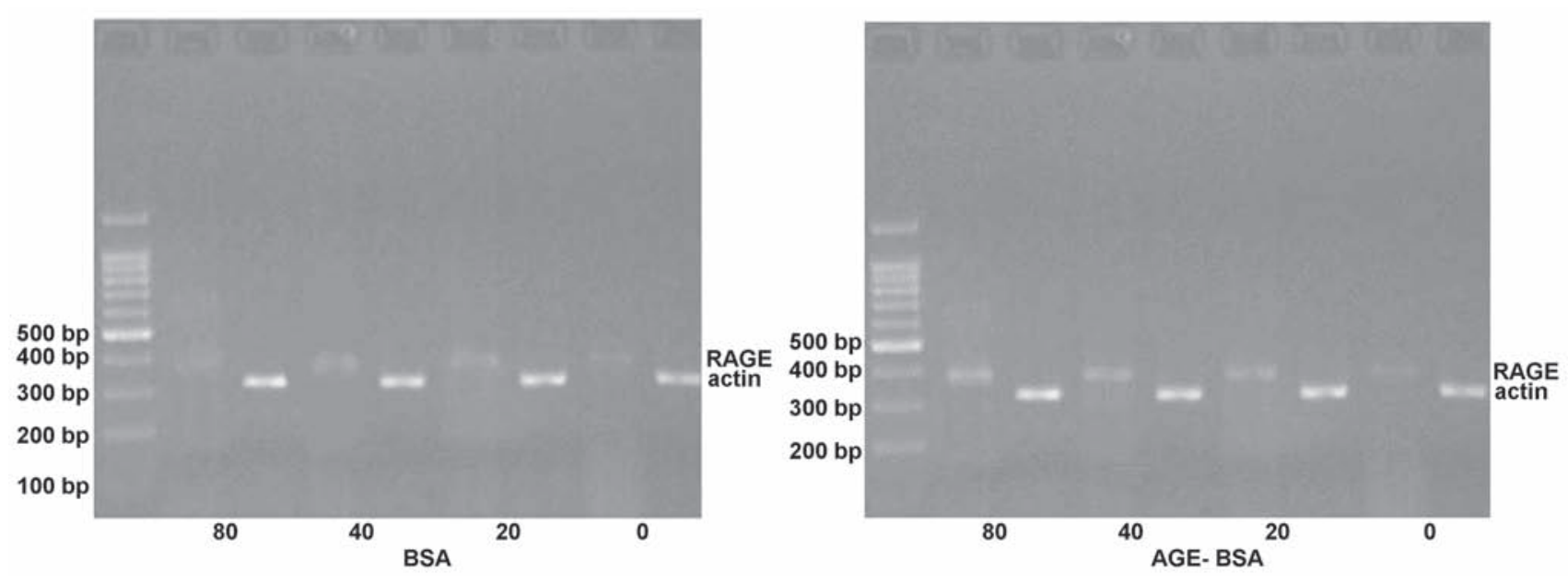

Figure 2. Expression of RAGE mRNA in SH-SY5Y cells treated by different concentrations of BSA and AGE-BSA. BSA, bovine serum albumin; AGE, advanced glycation end-product; RAGE, receptor for AGE.

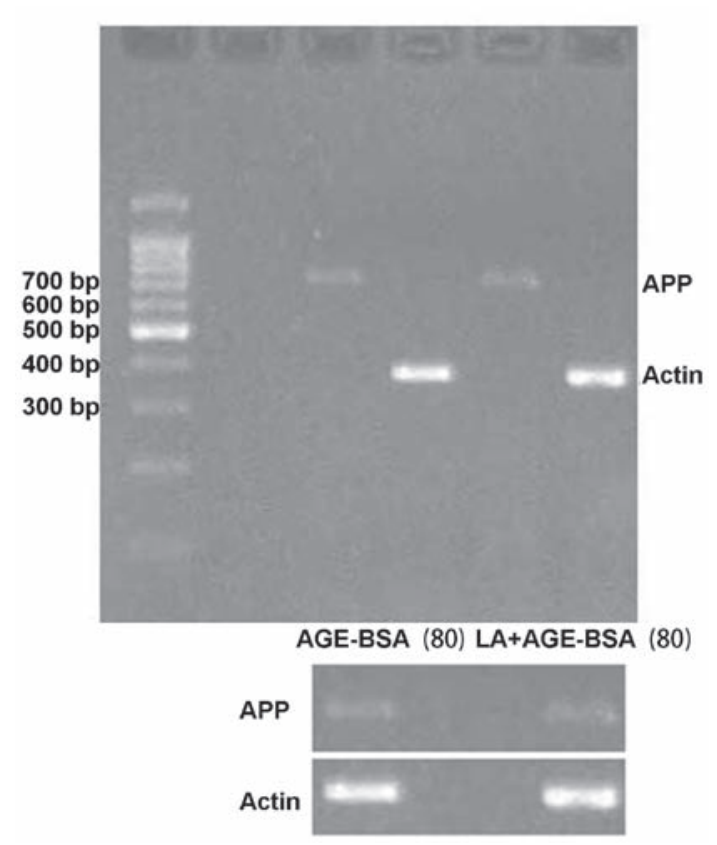

Figure 3. Levels of APP mRNA expression in SH-SY5Y cells that were intervened by LA before treatment with $80 \mu \mathrm{g} / \mathrm{ml}$ AGE-BSA. BSA, bovine serum albumin; AGE, advanced glycation end-product; APP, amyloid precursor protein; LA, lipoic acid.

was no evidence of any changes in APP mRNA expression as compared with the control group (Table X and Fig. 4).

\section{Discussion}

Recent studies showed that AGEs play a very important role in the pathogenic process of neurodegenerative diseases, and such studies mainly focused on the direct toxic effect of AGEs on neurons. Sasaki et al found that there were many AGEs deposited in SP, NFTS, microglial cells and astrocytes in the brain tissue of AD patients (18). It was also indicated that AGE precursors such as methylglyoxal, glyoxal and HNE displayed cytotoxicity independently of $A \beta$, and further promoted $A \beta$ aggregation (16). Takeuchi et al employed chicken egg albumin

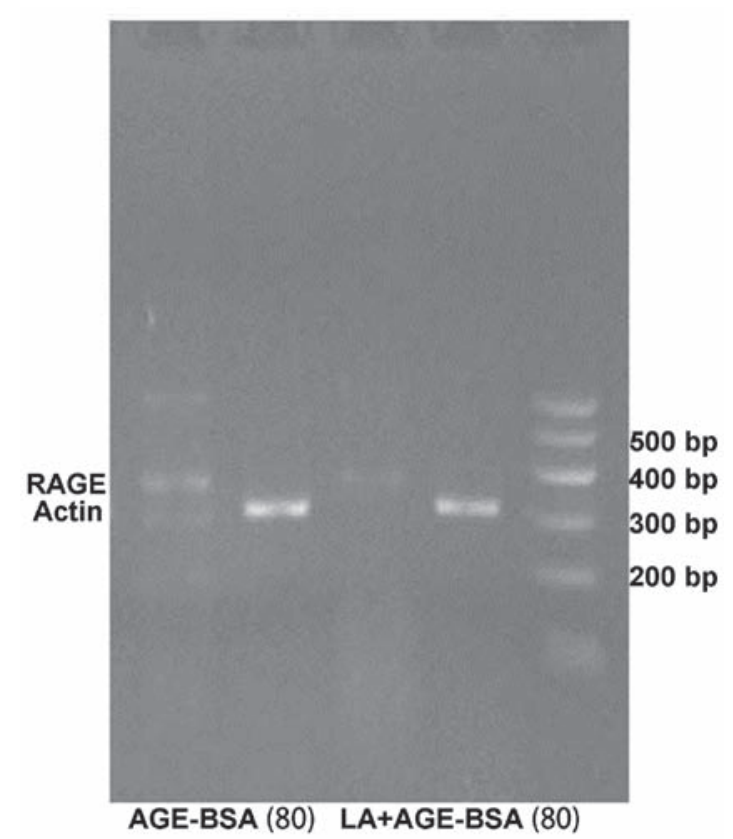

Figure 4. Levels of RAGE mRNA expression in SH-SY5Y cells that were intervened by LA before treatment with $80 \mu \mathrm{g} / \mathrm{ml}$ AGE-BSA. BSA, bovine serum albumin; AGE, advanced glycation end-product; RAGE, receptor for AGE; LA, lipoic acid.

and BSA-AGEs to treat SH-SY5Y cells, primary astrocytes and N9 cells, which led to cell death (17).

The neurotoxic mechanism of AGEs remains unclear. It was reported that AGEs could indirectly modify A $\beta$ in SP and tau protein in NFTS, and that the protein modified by AGEs were cytotoxic, a property that increased with the extent of modification (19). However, the inflammatory response generated by glycosylated $A \beta$ simulating the microglial cell was much more severe than that of non-glycosylated $A \beta(20)$. In vitro, $\mathrm{A} \beta$ formed a core with AGEs, which provoked additional aggregation by soluble $A \beta$. The unmodified $A \beta$ as signal combined with the receptor for AGEs induced gene expression and aggravated the glycosylated process.

The modified tau protein could cause abnormal phosphorylation and cross-linking and significantly decreased 
Table IX. Levels of APP mRNA expression in SH-SY5Y cells that were intervened by LA before treatment with $80 \mu \mathrm{g} / \mathrm{ml}$ AGE-BSA.

\section{Groups $(\mathrm{g} / \mathrm{l})$}

APP mRNA/actin mRNA

$80 \mu \mathrm{g} / \mathrm{ml}$ AGE-BSA
$0.1 \mathrm{~g} / \mathrm{l} \alpha-\mathrm{LA}$
Control

Data are presented as the means $\pm \mathrm{SD}$. vs. control, ${ }^{\mathrm{a}} \mathrm{P}>0.05$. BSA, bovine serum albumin; AGE, advanced glycation end-product; SD, standard deviation; APP, amyloid precursor protein; LA, lipoic acid.

Table X. Levels of RAGE mRNA expression in SH-SY5Y cells intervened by LA before treatment with $80 \mu \mathrm{g} / \mathrm{ml}$ AGE-BSA $($ mean $\pm \mathrm{SD})$.

\begin{tabular}{lc} 
Groups $(\mathrm{g} / \mathrm{l})$ & RAGE mRNA/actin m \\
\hline $80 \mu \mathrm{g} / \mathrm{ml}$ AGE-BSA & $0.591 \pm 0.040$ \\
$0.1 \mathrm{~g} / \mathrm{l} \alpha-\mathrm{LA}$ & $0.543 \pm 0.030^{\mathrm{a}}$ \\
Control & $0.49 \pm 0.017$
\end{tabular}

Data are presented as the means $\pm \mathrm{SD}$. vs. control, ${ }^{\mathrm{a}} \mathrm{P}<0.05$. BSA, bovine serum albumin; AGE, advanced glycation end-product; SD, standard deviation; LA, lipoic acid.

microtubule assembly, further promoting pathologic changes commonly seen in AD. It was reported that AGE-modified MAP-tau would result in increased APP expression and increased formation of $\mathrm{A} \beta$ when introduced into the neuron. However, in our study, it was demonstrated that AGE-BSA also directly improved $A \beta$ formation in a concentration-dependent manner, suggesting increased formation of $A \beta$ is involved in the cytotoxicity of AGEs. Moreover, it was also revealed that there was no clear alteration of APP mRNA expression in SH-SY5Y cells at $48 \mathrm{~h}$ after being treated by different protein concentrations $(20,40$ and $80 \mu \mathrm{g} / \mathrm{ml})$ in the RT-PCR test. It was speculated that the increased formation of $\mathrm{A} \beta$ was not caused by an increase in APP expression as a result of increased APP mRNA expression. It was also reported that the toxic effect of AGEs were predominantly mediated by oxidative stress (21). Maczurek et al (22) found that there was AGE-specific receptor on the surface of neurogliocytes. It was combined with AGEs and further activated intracellular signal transduction pathway, which resulted in the generation of many cytokines and oxidative stress. Misonou et al (23) used $\mathrm{H}_{2} \mathrm{O}_{2}$ to study the effect of oxidative stress on SH-SY5Y cells, and found that it decreased $\mathrm{COOH}$-terminal fragments in the $\beta$-secretase pathway. Cho et al (24) proved that the RAGE signaling pathway could enhance BACEI expression by activating NFAJI both in vitro and in vivo, further causing increases in $A \beta$ formation. Furthermore, AGE-RAGE could play a part by inducing CTGF expression, and not necessarily by oxidative stress $(25,26)$.

In addition, we also confirmed that AGE-BSA induced increases in RAGE mRNA expression in SH-SY5Y cells.
RAGE is the receptor of $A \beta$, and its expression would be increased in the abundant $A \beta$ environment (27). It was also combined with $A \beta$ at the nanomole level and amplified the neuronal damage that was mediated by $\mathrm{A} \beta$ (28). In the in vitro study, the combination of $A \beta$ and RAGE could activate $\mathrm{NF}-\kappa \mathrm{B}$ and simulate secretion of macrophage colony stimulating factor (M-CSF) and IL-6, suggesting that A $\beta$-RAGE played a very important role in the neuronal inflammatory response (29). A prior study found that in a transgenic rat model that expressed both neuronal RAGE and APP showed evident cognitive disorder and decreased axonal conduction ability as compared the rat with normal expression of neuronal RAGE or APP in three to four month-old rats. At this time, the rat showed no characteristic pathological changes consistent with AD, indicating that the activation of RAGE by $A \beta$ could involve neuronal damage in the early stages of $\mathrm{AD}(6)$.

In our study, intracellular $A \beta$ expression was evidently increased after being treated by AGE-BSA, suggesting increased formation of $A \beta$. RAGE mRNA expression was increased, which was seen after $A \beta$ combined with neurons and RAGE expression being evident on the cytoplasmic membranes of oligodendroglia cells. Then, NF- $\kappa \mathrm{B}$ was initiated resulting in a persistent inflammatory response, neuronal cytotoxicity and cell death (30). However, in the environment with abundant $A \beta$, the expression was persistently increased, which amplified the pathogenic effect that was induced by $A \beta$ (31). Zlokovic (32) found that in the neurons of APP transgenic mice, the expression of RAGE accelerated the decrease in cognitive function and dysfunction of neurons that was induced by $\mathrm{A} \beta$. RAGE on the surface of encephalic vascular endothelial cells could assist $A \beta$ to pass through the blood-brain barrier in the peripheral circulation (33), upregulate CCR5 expression, and stimulate T cells that entered the endocardium, causing a systemic inflammatory response (34). Above all, as the ligand of RAGE, A $\beta$ could mutually interact, and thereby play a major role in cytotoxicity of AGE-BSA.

Moreover, since RAGE is the specific receptor of AGEs, it can mediate toxic effect of AGEs in many chronic diabetic complications. It was found that the combination of AGEs-RAGE also activated the NF- $\mathrm{NB}$ signaling pathway in microglial cells and astrocytes (20), which was one of the promoters that regulated RAGE expression (35). The activation of site 1 and 2 upregulated RAGE expression, and further promoted the combination of AGEs and RAGE.

In addition, such combination also activated many pathways such as that of protein kinase $\mathrm{C}$ signaling, protein tyrosine kinases, and P21RAS, causing a coordinated cellular damage response (36). In short, AGEs possess evident toxicity against nerve cells, directly leading to increased formation of $A \beta$ and neurodegeneration. In the context of a toxic effect, the A $\beta$-RAGE combination, AGEs-RAGE combination, $A \beta$ and RAGE could all be involved. The increased formation of $A \beta$ would not be realized by increased APP expression caused by increased APP mRNA expression, the detailed mechanism requires further exploration.

The $\alpha$-LA with terminal concentrations of $0.01,0.1$ and $1 \mathrm{~g} / 1$ was employed to pre-treat SH-SY5Y cells for $30 \mathrm{~min}$ to study the influence of $\alpha$-LA on the toxic effects of nerve cells caused by AGEs. The results show that $\alpha$-LA at a dose of 

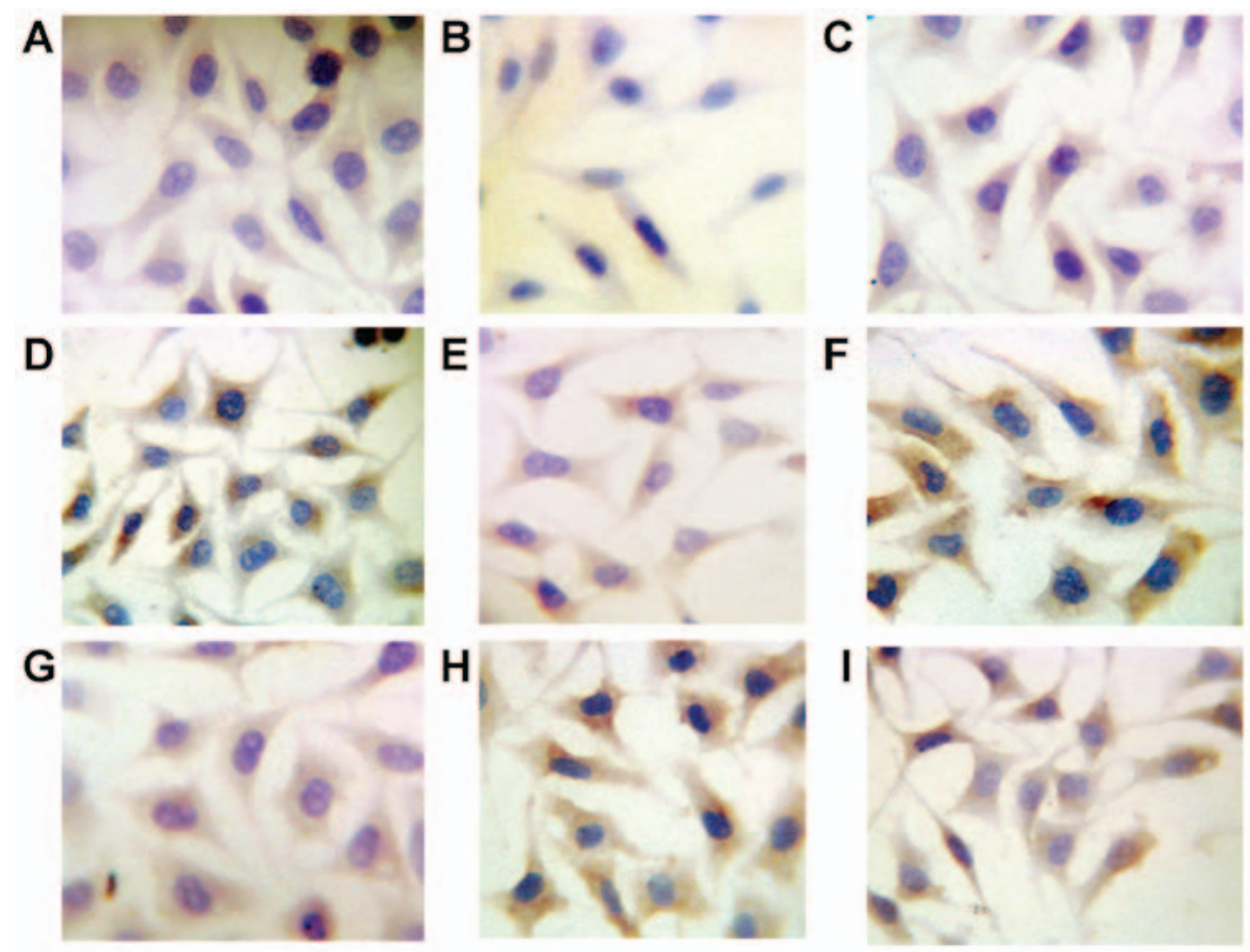

Figure 5. (A) 1-1 expression of A $\beta$ in normal SH-SY5Y (10x40); (B) the SH-SY5Y of negative control group (10x40); (C) 1-2 expression of A $\beta$ in SH-SY5Y treated by BSA(20 $\mu \mathrm{g} / \mathrm{ml})$ for $48 \mathrm{~h}(10 \mathrm{x} 40)$; (D) 1-3 Expression of A 3 in SH-SY5Y treated by AGE-BSA(20 $\mu \mathrm{g} / \mathrm{ml})$ for $48 \mathrm{~h}$ (10x40); (E) 1-4 expression of $\mathrm{A} \beta$ in SH-SY5Y treated by BSA $(40 \mu \mathrm{g} / \mathrm{ml})$ for $48 \mathrm{~h}(10 \mathrm{x} 40)$; (F) 1-5 expression of A 3 in SH-SY5Y treated by AGE-BSA $(40 \mu \mathrm{g} / \mathrm{ml})$ for $48 \mathrm{~h}(10 \mathrm{x} 40)$; (G) $1-6$ expression of A $\beta$ in SH-SY5Y treated by BSA $(80 \mu \mathrm{g} / \mathrm{ml})$ for $48 \mathrm{~h}(10 \mathrm{x} 40) ;(\mathrm{H}) 1-7$ expression of A $\beta$ in SH-SY5Y treated by AGE-BSA $(80 \mu \mathrm{g} / \mathrm{ml})$ for $48 \mathrm{~h}$ (10x40); (I) photo 1-8 expression of A $\beta$ in SH-SY5Y intervention by LA(0.1 g/l) $30 \mathrm{~min}$ before being treated by AGE-BSA(80 $\mu \mathrm{g} / \mathrm{ml})$ for $48 \mathrm{~h}(10 \mathrm{x} 40)$.

$0.1 \mathrm{~g} / \mathrm{l}$ significantly resisted the toxic effect of AGEs-BSA to SH-SY5Y. Compared with the corresponding control group, the MTT metabolic rate was significantly increased, $\mathrm{LDH}$ release was significantly decreased and cell morphology was greatly improved. It suggested that $\alpha$-LA had a protective effect for nerve cells.

In our study, we found that LA had a protective effect on nerve cells but not in a dose-dependent manner. Therefore, we deduced that LA entered cells by a certain carrier, and when the carrier was saturating, the effect would not be increased as the carrier supply. Moreover, increased LA concentration provoked altered osmotic pressure and $\mathrm{pH}$, directly influenced the external environment of incubated cells, and further influenced the effect of LA.

We chose $\alpha$-LA with an optimal concentration of $0.1 \mathrm{~g} / \mathrm{l}$ to pre-treat cells in the AGE-BSA $(80 \mu \mathrm{g} / \mathrm{ml})$ group for $30 \mathrm{~min}$ and then tested the influence of $\alpha$-LA on intracellular $A \beta$ protein, APP mRNA and TAGE mRNA expression profiles. We found that as compared with the corresponding AGEs-BSA treatment group, the intracellular $A \beta$ expression significantly decreased, which suggested that $\alpha$-LA was partly related to a decreased expression in $A \beta$, at least in the protection of SH-SY5Y cells (Fig. 5).

There was no evident change in APP mRNA expression, which suggested that decreased $A \beta$ was not realized by decreased APP expression that was caused by decreased APP mRNA expression. Furthermore, the expression of TAGE mRNA was significantly reduced. The results indicated that using an anti-RAGE antibody to prevent the combination of RAGE and ligand, significantly reduced the generation of inflammatory cytokines and nitric oxide by microglial cells (37).

The RAGE antagonist, sRAGE (soluble RAGE) was used to treat diabetic rats that lacked Apo-E. In this mode, treatment inhibited development of early angiosclerosis (38). High doses of sRAGE to mouse would isolate $A \beta$ in the plasms, and would thus decrease intracranial $A \beta$ levels (31). It was deduced that the weakened combination of $A \beta$-RAGE and AGEs-RAGE were also involved in the protective effect of LA for nerve cells. AGEs decreased the intake of glucose into SH-SY5Y cells, which was related to the inactivation of the glucose transporter, as previously reported by Keller et al (ref.?) However, after LA enters cells, pyruvate dehydrogenase would be activated, which would thus increase aerobic metabolism of glucose. Besides, it also made the glucose transporter (GLUT1, GLUT3, and GLUT4) translocate to the cytoplasmic membrane by activating phosphatidylinositol-3. Therefore, $\alpha$-LA possibly enabled neuronal cells to resist damage that was caused by AGEs-BSA via improving glucose metabolism. The effect of decreased $A \beta$ formation on improving glycometabolism still requires further exploration.

In conclusion, we found that $\mathrm{A} \beta$ is the key factor for $\mathrm{AD}$ pathological mechanisms, which is also an important target for $\mathrm{AD}$ treatment. In addition, $\alpha$-LA could reduce $\mathrm{A} \beta$ generation and inhibit $A \beta$ aggregation, and it also demonstrated utility in absorbing and passing through the blood-brain barrier, thus playing a very important role in the central nervous system degenerative diseases. Thus, we believe that $A \beta$ should have wide developmental utility in the future. 


\section{Acknowledgements}

Not applicable.

\section{Funding}

No funding was received.

\section{Availability of data and material}

The datasets used and/or analyzed during the current study are available from the corresponding author on reasonable request.

\section{Authors' contributions}

GN and JG carried out the studies, participated in collecting data, and drafted the manuscript. YT and $\mathrm{KZ}$ performed the statistical analysis and participated in its design. JL was also involved in the conception of the study and helped to draft the manuscript. QX helped to design the studies and modified the manuscript. All authors read and approved the final manuscript.

\section{Ethics approval and consent to participate}

Not applicable.

\section{Consent for publication}

Not applicable.

\section{Competing interests}

The authors declare that they have no competing interests.

\section{References}

1. Biessels GJ, Staekenborg S, Brunner E, Brayne C and Scheltens P: Risk of dementia in diabetes mellitus: A systematic review. Lancet Neurol 5: 64-74, 2006.

2. Lu FP, Lin KP and Kuo HK: Diabetes and the risk of multi-system aging phenotypes: A systematic review and meta-analysis. PLoS One 4: e4144, 2009.

3. Cukierman T, Gerstein HC and Williamson JD: Cognitive decline and dementia in diabetes-systematic overview of prospective observational studies. Diabetologia 48: 2460-2469, 2005.

4. Vasan S, Foiles PG and Founds HW: Therapeutic potential of AGE inhibitors and breakers of AGE protein cross-links. Expert Opin Investig Drugs 10: 1977-1987, 2001.

5. Gong CX, Liu F, Grundke-Iqbal I and Iqbal K: Impaired brain glucose metabolism leads to Alzheimer neurofibrillary degeneration through a decrease in tau O-GlcNAcylation. J Alzheimers Dis 9: 1-12, 2006.

6. Arancio O, Zhang HP, Chen X, Lin C, Trinchese F, Puzzo D, Liu S, Hegde A, Yan SF, Stern A, Luddy JS, et al: RAGE potentiates Abeta-induced perturbation of neuronal function in transgenic mice. EMBO J 23: 4096-4105, 2004.

7. Lefebvre T, Ferreira S, Dupont-Wallois L, Bussière T, Dupire MJ, Delacourte A, Michalski JC and Caillet-Boudin ML: Evidence of a balance between phosphorylation and O-GlcNAc glycosylation of Tau proteins-a role in nuclear localization. Biochim Biophys Acta 1619: 167-176, 2003

8. Hoyer S: Causes and consequences of disturbances of cerebral glucose metabolism in sporadic Alzheimer disease: Therapeutic implications. Adv Exp Med Biol 541: 135-152, 2004.

9. Guglielmotto M, Aragno M, Tamagno E, Vercellinatto I, Visentin S, Medana C, Catalano MG, Smith MA, Perry G, Danni O, et al: AGEs/RAGE complex upregulates BACE1 via NF-kappaB pathway activation. Neurobiol Aging 33: 196 e113-127, 2012.
10. Farr SA, Price TO, Banks WA, Ercal N and Morley JE: Effect of alpha-lipoic acid on memory, oxidation, and lifespan in SAMP8 mice. J Alzheimers Dis 32: 447-455, 2012.

11. Shinto L, Quinn J, Montine T, Dodge HH, Woodward W, Baldauf-Wagner S, Waichunas D, Bumgarner L, Bourdette D, Silbert L, et al: A randomized placebo-controlled pilot trial of omega-3 fatty acids and alpha lipoic acid in Alzheimer's disease. J Alzheimers Dis 38: 111-120, 2014.

12. Galasko DR, Peskind E, Clark CM, Quinn JF, Ringman JM, Jicha GA, Cotman C, Cottrell B, Montine TJ, Thomas RG, et al; Alzheimer's Disease Cooperative Study: Antioxidants for Alzheimer disease: A randomized clinical trial with cerebrospinal fluid biomarker measures. Arch Neurol 69: 836-841, 2012.

13. Hager K, Marahrens A, Kenklies M, Riederer P and Münch G: Alpha-lipoic acid as a new treatment option for Alzheimer [corrected] type dementia. Arch Gerontol Geriatr 32: 275-282, 2001.

14. Zhang L, Xing GQ, Barker JL, Chang Y, Maric D, Ma W, Li BS and Rubinow DR: Alpha-lipoic acid protects rat cortical neurons against cell death induced by amyloid and hydrogen peroxide through the Akt signalling pathway. Neurosci Lett 312: 125-128, 2001.

15. Ono K, Hirohata M and Yamada M: Alpha-lipoic acid exhibits anti-amyloidogenicity for beta-amyloid fibrils in vitro. Biochem Biophys Res Commun 341: 1046-1052, 2006.

16. Woltjer RL, Maezawa I, Ou JJ, Montine KS and Montine TJ: Advanced glycation endproduct precursor alters intracellular amyloid-beta/A beta PP carboxy-terminal fragment aggregation and cytotoxicity. J Alzheimers Dis 5: 467-476, 2003.

17. Takeuchi M, Bucala R, Suzuki T, Ohkubo T, Yamazaki M, Koike T, Kameda Y and Makita Z: Neurotoxicity of advanced glycation end-products for cultured cortical neurons. J Neuropathol Exp Neurol 59: 1094-1105, 2000.

18. Sasaki N, Fukatsu R, Tsuzuki K, Hayashi Y, Yoshida T, Fujii N, Koike T, Wakayama I, Yanagihara R, Garruto R, et al: Advanced glycation end products in Alzheimer's disease and other neurodegenerative diseases. Am J Pathol 153: 1149-1155, 1998.

19. Saxena P, Saxena AK, Cui XL, Obrenovich M, Gudipaty K and Monnier VM: Transition metal-catalyzed oxidation of ascorbate in human cataract extracts: Possible role of advanced glycation end products. Invest Ophthalmol Vis Sci 41: 1473-1481, 2000.

20. Singh R, Barden A, Mori T and Beilin L: Advanced glycation end-products: A review. Diabetologia 44: 129-146, 2001.

21. Münch G, Kuhla B, Lüth HJ, Arendt T and Robinson SR: Anti-AGEing defences against Alzheimer's disease. Biochem Soc Trans 31: 1397-1399, 2003.

22. Maczurek A, Shanmugam K and Münch G: Inflammation and the redox-sensitive AGE-RAGE pathway as a therapeutic target in Alzheimer's disease. Ann N Y Acad Sci 1126: 147-151, 2008.

23. Misonou H, Morishima-Kawashima M and Ihara Y: Oxidative stress induces intracellular accumulation of amyloid beta-protein (Abeta) in human neuroblastoma cells. Biochemistry 39: 6951-6959, 2000

24. Cho HJ, Son SM, Jin SM, Hong HS, Shin DH, Kim SJ, Huh K and Mook-Jung I: RAGE regulates BACE1 and Abeta generation via NFAT1 activation in Alzheimer's disease animal model. FASEB J 23: 2639-2649, 2009.

25. Twigg SM, Chen MM, Joly AH, Chakrapani SD, Tsubaki J, Kim HS, Oh Y and Rosenfeld RG: Advanced glycosylation end products up-regulate connective tissue growth factor (insulin-like growth factor-binding protein-related protein 2) in human fibroblasts: A potential mechanism for expansion of extracellular matrix in diabetes mellitus. Endocrinology 142: 1760-1769, 2001.

26. Hughes JM, Kuiper EJ, Klaassen I, Canning P, Stitt AW, Van Bezu J, Schalkwijk CG, Van Noorden CJ and Schlingemann RO: Advanced glycation end products cause increased $\mathrm{CCN}$ family and extracellular matrix gene expression in the diabetic rodent retina. Diabetologia 50: 1089-1098, 2007.

27. Deane R, Du Yan S, Submamaryan RK, LaRue B, Jovanovic S, Hogg E, Welch D, Manness L, Lin C, Yu J, et al: RAGE mediates amyloid-beta peptide transport across the blood-brain barrier and accumulation in brain. Nat Med 9: 907-913, 2003.

28. Brady MJ, Bourbonais FJ and Saltiel AR: The activation of glycogen synthase by insulin switches from kinase inhibition to phosphatase activation during adipogenesis in 3T3-L1 cells. J Biol Chem 273: 14063-14066, 1998.

29. Wang HY, Lee DH, D'Andrea MR, Peterson PA, Shank RP and Reitz AB: beta-Amyloid(1-42) binds to alpha7 nicotinic acetylcholine receptor with high affinity. Implications for Alzheimer's disease pathology. J Biol Chem 275: 5626-5632, 2000. 
30. Onyango IG, Tuttle JB and Bennett JP Jr: Altered intracellular signaling and reduced viability of Alzheimer's disease neuronal cybrids is reproduced by beta-amyloid peptide acting through receptor for advanced glycation end products (RAGE). Mol Cell Neurosci 29: 333-343, 2005.

31. Deane R, Singh I, Sagare AP, Bell RD, Ross NT, LaRue B, Love R, Perry S, Paquette N, Deane RJ, et al: A multimodal RAGE-specific inhibitor reduces amyloid $\beta$-mediated brain disorder in a mouse model of Alzheimer disease. J Clin Invest 122: 1377-1392, 2012.

32. Zlokovic BV: Neurovascular mechanisms of Alzheimer's neurodegeneration. Trends Neurosci 28: 202-208, 2005.

33. Baiguera S, Fioravanzo L, Grandi C,DiLiddo R, Parnigotto PP and Folin M: Involvement of the receptor for advanced glycation-end products (RAGE) in $\beta$-amyloid-induced toxic effects in rat cerebromicrovascular endothelial cells cultured in vitro. Int J Mol Med 24: 9-15, 2009

34. Li M, Shang DS, Zhao WD, Tian L, Li B, Fang WG, Zhu L, Man SM and Chen YH: Amyloid beta interaction with receptor for advanced glycation end products up-regulates brain endothelial CCR5 expression and promotes T cells crossing the blood-brain barrier. J Immunol 182: 5778-5788, 2009.
35. Wong A, Lüth HJ, Deuther-Conrad W, Dukic-Stefanovic S, Gasic-Milenkovic J, Arendt T and Münch G: Advanced glycation endproducts co-localize with inducible nitric oxide synthase in Alzheimer's disease. Brain Res 920: 32-40, 2001.

36. Boulanger E, Dequiedt P and Wautier JL: Advanced glycosylation end products (AGE): New toxins? Nephrologie 23: 351-359, 2002 (In French).

37. Berbaum K, Shanmugam K, Stuchbury G, Wiede F, Körner H and Münch G: Induction of novel cytokines and chemokines by advanced glycation endproducts determined with a cytometric bead array. Cytokine 41: 198-203, 2008.

38. Anzai Y, Hayashi M, Fueki N, Kurata K and Ohya T: Protracted juvenile neuronal ceroid lipofuscinosis - an autopsy report and immunohistochemical analysis. Brain Dev 28: 462-465, 2006. 